Irena Galińska-Rączy

\title{
Ocena petycji Andrzeja Halickiego w sprawie nowelizacji ustawy o petycjach w zakresie zamieszczania odpowiedzi na petycję na stronie internetowej podmiotu rozpatrującego petycję oraz zmiany terminu przekazania petycji podmiotowi właściwemu do jej rozpatrzenia'
}

\begin{abstract}
Assessment of Andrzej Halicki's petition concerning amendment of the Act on Petitions as regards publishing a reply to a petition on a website of a respective entity and modifying deadline for transferring petition to a competent entity (WAP-936/18): In the author's opinion the proposed amendments are reasonable and admissible as concerns a legislator's discretion. Such amendment would lead to making proceedings with petitions more transparent and may eliminate an inconsistency between an obligation to publish a scan of a petition and the lack of such obligation regarding a reply to the petition. Moreover, the author supports reducing the deadline for transferring a petition to a competent entity, e.g. to 14 days.
\end{abstract}

Keywords: petition, administrative proceedings

Słowa kluczowe: petycja, postępowanie administracyjne

Ekspert ds. legislacji BAS; irena.galinska-raczy@sejm.gov.pl.

\section{Treść i cel petycji}

Petycja nr BKSP-145-343/18 (dalej: petycja) została wniesiona przez Andrzeja Halickiego (wnoszący petycję złożył oświadczenie o wyrażeniu zgody na publikację petycji z podaniem jego imienia i nazwiska). Petycja zawiera wniosek do-

Opinia prawna dotyczaca petycji Andrzeja Halickiego w sprawie nowelizacji ustawy z dnia 11 lipca 2014 r. o petycjach w zakresie zamieszczania odpowiedzi na petycję na stronie internetowej podmiotu rozpatrującego petycję oraz zmiany terminu przekazania petycji podmiotowi właściwemu do jej rozpatrzenia sporządzona 15 maja 2018 r. na zlecenie przewodniczącego Komisji do Spraw Petycji; BAS-WAP-936/18. 
tyczący zmiany ustawy z 11 lipca 2014 r. o petycjach (Dz.U. 2017, poz. 1123, ze zm.; dalej: ustawa) w zakresie:

- zamieszczania na stronie internetowej podmiotu rozpatrującego petycję skanu odpowiedzi na petycję wniesioną w interesie publicznym (zmiana art. 8 lub art. 13),

- skrócenia terminu przekazania petycji przez adresata petycji niewłaściwego do jej rozpatrzenia do podmiotu właściwego z 30 dni do 14 dni (zmiana art. 6 ust. 1).

Wnoszący petycję proponuje konkretne rozwiązania legislacyjne, przedstawiając nową treść art. 8 ust. 3 (lub art. 13 ust. 3) ustawy oraz art. 6 ust. 1 tego aktu. W petycji zaproponowano:

- dodanie do art. 8 (lub art. 13) ust. 3 w brzmieniu: Na stronie internetowej podmiotu rozpatrujacego petycję lub urzędu go obsługujacego niezwłocznie zamieszcza się informację zawierająca odwzorowanie cyfrowe (skan) odpowiedzi na petycje wniesionej $w$ interesie publicznym,

- zmianę ust. $1 \mathrm{w}$ art. 6 ustawy $^{2}$ poprzez zastąpienie określenia „30 dni” określeniem „14 dni”.

\section{Czy petycja mieści się w zakresie zadań i kompetencji adresata petycji (art. 2 ust. 3 ustawy o petycjach)?}

Petycja będąca przedmiotem niniejszej opinii obejmuje żądanie zmiany przepisów prawa o randze ustawy. Zgodnie z art. 95 ust. 1 Konstytucji RP władzę ustawodawczą w Rzeczypospolitej Polskiej sprawują Sejm i Senat. Natomiast stosownie do art. 118 ust. 1 Konstytucji RP inicjatywa ustawodawcza przysługuje m.in. posłom. Artykuł 32 ust. 2 regulaminu Sejmu, w związku z art. 112 Konstytucji $\mathrm{RP}$, precyzuje, że poselskie projekty ustaw mogą być wnoszone przez komisje sejmowe lub grupę co najmniej 15 posłów podpisujących projekt.

Uwzględniając powyższe, należy uznać, że petycja mieści się w zakresie zadań i kompetencji Sejmu.

\section{Wymogi formalne (art. 4 ust. 1 i ust. 2 oraz art. 12 ustawy o petycjach)}

Petycja spełnia wymogi formalne określone w art. 4 ust. 1 i ust. 2 ustawy o petycjach (zawiera prawidłowe oznaczenie podmiotu wnoszącego petycję oraz wskazanie przedmiotu petycji).

$2 \quad$ Art. 6. 1. Adresat petycji, który jest niewłaściwy do jej rozpatrzenia, przesyła ją niezwłocznie, nie później jednak niż w terminie 30 dni od dnia jej złożenia, do podmiotu właściwego do rozpatrzenia petycji, zawiadamiając o tym równocześnie podmiot wnoszacy petycję. 
Przystępując do merytorycznej oceny propozycji zawartych w petycji, należy zauważyć, że w zakresie nowelizacji art. 8 ustawy autor wniósł wcześniej do Sejmu (28 grudnia 2016 r.) petycję o dokonanie takiej zmiany (petycja nr BKSP145-171/16). Petycja ta została rozpatrzona negatywnie przez Komisję do Spraw Petycji Sejmu RP na posiedzeniu w dniu 20 kwietnia 2017 r. Proponowana obecnie przez A. Halickiego nowelizacja art. 8 (lub 13) różni się od poprzedniej tym, że obowiązek zamieszczania skanu odpowiedzi na petycję odnosiłby się tylko do petycji wnoszonych w interesie publicznym. W petycji zawarto również propozycję dotyczącą zmiany art. 6 ustawy o petycjach.

Nie jest to zatem petycja identyczna z petycją poprzednią, a w związku z tym wątpliwe byłoby zastosowanie do niej art. 12 ust. 1 ustawy ${ }^{3}$ (czyli pozostawienie petycji bez rozpatrzenia), zwłaszcza że Komisja do Spraw Petycji nie uwzględniając żądania będącego przedmiotem petycji z 28 grudnia 2016 r., kierowała się m.in. tym, że „ustawa działa stosunkowo krótko”" a jednocześnie rozważała w przyszłości (np. pod koniec 2017 r.) ponowną analizę zagadnienia zgłoszonego w petycji ${ }^{5}$.

\section{Kwestie, które ekspert uznaje za istotne w związku z petycją}

1. Uzasadniając konieczność nowelizacji art. 8 ust. 3 (lub art. 13 ust. 3) ustawy autor powtarza argumentację zawartą w petycji z 28 grudnia 2016 r. Odnosząc się do tej argumentacji oraz proponowanej treści przepisu (art. 8 ust. 3 lub 13 ust. 3 ustawy), należy przypomnieć, że w opinii Biura Analiz Sejmowych ${ }^{6}$ sporządzonej 15 marca 2017 r. przez prof. dr. hab. A. Szmyta rekomendowano pozytywne załatwienie petycji, wyrażając przekonanie, że wnoszący petycję słusznie wskazuje na: „niesymetryczność, pewna nielogiczność rozwiązania, skoro ustawodawca zdecydował o obowiązku zamieszczania skanu "petycji”, a pominą obowiązek zamieszczania skanu „odpowiedzi na petycję". Jednocześnie w opinii tej za słuszny uznano pogląd, że przyjęcie rozwiązania proponowanego w petycji

3 Art. 12. 1. Podmiot właściwy do rozpatrzenia petycji może pozostawić bez rozpatrzenia petycję złożona $w$ sprawie, która była przedmiotem petycji już rozpatrzonej przez ten podmiot, jeżeli w petycji nie powołano się na nowe fakty lub dowody nieznane podmiotowi właściwemu do rozpatrzenia petycji.

2. W przypadku, o którym mowa $w$ ust. 1, podmiot właściwy do rozpatrzenia petycji niezwłocznie informuje podmiot wnoszacy petycje o pozostawieniu petycji bez rozpatrzenia i poprzednim sposobie załatwienia petycji.

4 Wypowiedź poseł U. Augustyn na 74. posiedzeniu Komisji do spraw Petycji w dniu 20 kwietnia 2017 r., http://www.sejm.gov.pl/Sejm8.nsf/biuletyn.xsp?skrnr=PET-74.

Wypowiedzi posłów S.J. Piechoty i U. Augustyn - ibidem.

6 Opinia prawna dotyczaca petycji A.H. $z$ dnia 28 grudnia 2016 r. do Marszałka Sejmu w sprawie podjęcia działań w celu zmiany ustawy o petycjach, BAS-WAUiP 364/17. 
służyłoby transparentności procesu rozpatrywania petycji, zwłaszcza że obowiązujące przepisy pozwalają osobie postronnej na uzyskanie odpowiedzi na petycję w trybie ustawy z 6 września 2001 r. o dostępie do informacji publicznej (t.j. Dz.U. 2016, poz. 1764, ze zm.). W opinii zwrócono również uwagę na kontekst obywatelskiego prawa do informacji (gwarantowanego w art. 61 Konstytucji $\mathrm{RP}$ ), odnosząc to prawo do umożliwienia obywatelom zapoznania się ze stanowiskiem podmiotu, do którego wniesiono petycję (a nie tylko podmiotowi, który wniósł petycję).

2. Podzielając powyższą ocenę, należałoby wskazać na poglądy wyrażane w literaturze przedmiotu na temat konieczności zachowania jawności i przejrzystości procedury rozpatrywania petycji. Przepisy ustawy o petycjach powinny zapewniać jawność zarówno treści samej petycji, jak i transparentność przebiegu postępowania w sprawach dotyczących petycji, w tym sposobu jej załatwienia. W literaturze podkreśla się, że art. 8 budzi z tego punktu widzenia zastrzeżenia i ustawodawca powinien sprecyzować, że podmioty prowadzące strony podmiotowe Biuletynu Informacji Publicznej (czyli podlegające ustawie o dostępie do informacji publicznej): niezwłocznie udostęniaja na BIP kopie petycji w postaci elektronicznej oraz dane dotyczace przebiegu postępowania, a w szczególności dotyczace zasieganych opinii, przewidywanego terminu oraz sposobu załatwienia petycji ${ }^{7}$.

Z tego względu propozycja zawarta w petycji jest słuszna, bowiem doprecyzowuje zakres informacji, jakie powinny podlegać upublicznieniu. W doktrynie wskazuje się, że obowiązek aktualizacji informacji w zakresie określonym w art. 8 ust. 2 ustawy: to minimum oczekiwane przez ustawodawce, lecz nie ma przeszkód, aby zakres informacji publikowanych elektronicznie był szerszy ${ }^{8}$. Problem polega na tym, jak wykazał to autor w petycji z 28 grudnia 2016 r. (pokazując przykłady stron internetowych dwóch ministerstw, w tym Ministerstwa Sprawiedliwości, na których posłużono się ogólnikową formułą „Odpowiedź na petycję została udzielona wnoszącemu w dniu...” oraz „W dniu ... udzielono odpowiedzi podmiotowi wnoszącemu"9), że podmioty rozpatrujące petycje zazwyczaj ograniczają się do tego minimum.

7 D. Sybilski, Zagadnienie jawności i dostęp do akt w postępowaniach uproszczonych w sprawach skarg, wniosków i petycji [w:] Skargi, wnioski i petycje - powszechne środki ochrony prawnej, red. M. Błachucki, G. Sibiga, Wrocław 2017, s. 95.

8 M. Ożóg, Uregulowanie instytucji petycji w ustawie $z$ dnia 11 lipca 2014 r. o petycjach, „Przegląd Sejmowy” 2015, nr 5(130), s. 135.

9 Ten sposób jest nadal stosowany w Ministerstwie Sprawiedliwości (zob. np. Petycja została załatwiona poprzez odniesienie się do postulatów $w$ niej zawartych i przesłanie jej autorowi odpowiedzi wraz z uzasadnieniem droga elektroniczna $w$ dniu 17 listopada 2017 r. oraz $w$ formie pisemnej, https://bip.ms.gov.pl/pl/kontakt/petycje/zlozone-petycje/news,9918,petycja-w-sprawie-skladania-dokumentow-do.html). 
Należy również odnotować, że w przypadku niektórych podmiotów przyjęto stałą praktykę zamieszczania skanów lub elektronicznych wersji odpowiedzi udzielanych autorom petycji ${ }^{10}$, a nawet wprowadzono przepisy wewnętrzne nakazujące zamieszczanie skanu odpowiedzi na petycję ${ }^{11}$.

W związku z tym ostatnim stwierdzeniem, można uznać, że propozycja zmiany ustawy, o którą wnosi A. Halicki, stanowiłaby dla niektórych podmiotów potwierdzenie dla stosowanej przez nie praktyki, a jednocześnie byłaby wypełnieniem wskazywanego w doktrynie ratio legis art. 8 ust. 2 ustawy (również w kontekście art. 61 Konstytucji RP) oraz art. 63 Konstytucji RP.

3. Istotnym elementem propozycji nowelizacji art. 8 lub art. 13 ustawy zawartym w petycji jest ograniczenie obowiązku zamieszczania skanów odpowiedzi na petycję tylko do petycji podejmowanych w interesie publicznym. Zgodnie $\mathrm{z}$ art. 2 ust. 2 ustawy petycja może być złożona w interesie:

- publicznym,

- podmiotu wnoszącego petycję,

- podmiotu trzeciego, za jego zgodą.

W literaturze zwrócono uwagę zarówno na niejednoznaczność pojęć „interes publiczny”, „interes podmiotu wnoszącego petycję” oraz „interes podmiotu trzeciego", jak i na fakt, że interes publiczny może przeplatać się z interesem własnym $^{12}$.

10 Wśród pozytywnych przykładów podmiotów, które zamieszczają skany odpowiedzi na petycje, wskazać należy Ministerstwo Kultury i Dziedzictwa Narodowego, Rzecznika Praw Obywatelskich i Wojewódzki Sąd Administracyjny w Warszawie. Zob. http:// bip.mkidn.gov.pl/media/docs/petycje/2016/20161018_odpowiedz_na_petycje_p-Cislo.pdf; http://bip.mkidn.gov.pl/media/docs/petycje/2018/20180110;odpowiedź_ na_petycje_w_sprawie_bezpieczenstwa_internetowego.pdf; http://www.bip.brpo. gov.pl/pl/petycja/bdg-wpso05322017 (nota bene przedmiotem tej petycji była kwestia związana z publikacją na stronie BIP RPO odpowiedzi na petycje wnoszone do RPO); http://bip.warszawa.wsa.gov.pl/264/850/petycje-jednostkowe.html.

11 Zarządzenie nr 17/2018/DSS Prezesa Narodowego Funduszu Zdrowia w sprawie przyjmowania i rozpatrywania petycji w Narodowym Funduszu Zdrowia z dnia 1 marca 2018 r., Biuletyn Informacyjny NFZ z 2018 r. poz. 17, zał. nr 2.

12 A. Preisner, P. Kuczma, Zakres przedmiotowy prawa petycji i jego ograniczenia [w:] Teoretyczne i praktyczne aspekty realizacji prawa petycji, red. R. Balicki, M. Jabłoński, Wrocław 2015, s. 419-420. Autor przypomina, że kategoria „interesu” była podważana w toku prac legislacyjnych nad art. 63 Konstytucji, ponieważ: $z$ prawnego punktu widzenia nie jest możliwe precyzyjne ustalenie, $w$ czyim interesie wystapił autor (autorzy) - publicznym lub społecznym czy jak najbardziej egoistycznym własnym, grupowym czy indywidualnym. Czy np. petycja okolicznych mieszkańców przeciwko przeprowadzeniu w pobliżu ich mieszkań drogi szybkiego ruchu, hałaśliwej z natury rzeczy, ale potrzebnej danej społeczności jako całości, miastu jako takiemu, jest wywo- 
Uznaje się, że interes publiczny jest pojęciem niedookreślonym, które nie poddaje się jednoznacznej i uniwersalnej definicji, a jego znaczenie (...) powinno być ustalane każdorazowo w świetle okoliczności faktycznych, do których oceny ma ono zostać zastosowane (...). Nie oznacza to jednak, że nie jest możliwe ustalenie $w$ sposób ogólny pewnych zasadniczych elementów jego znaczenia. Można bowiem przyjąć, że pojęcie interesu publicznego odwotuje się zawsze do pewnych uznanych powszechnie $w$ społeczeństwie wartości, istotnych $z$ punktu widzenia jego prawidłowego funkcjonowania jako całości. Z tego też powodu przy ustalaniu jego treści w odniesieniu do konkretnego przypadku użyteczne będzie odwołanie się do celów $i$ wartości chronionych obowiązującym prawem, $w$ tym $w$ szczególności postanowieniami ustawy zasadniczej (...). Adresat petycji powinien więc każdorazowo badać relacje między żąaniami przedstawionymi w petycji a wartościami, których realizacja optymalizuje funkcjonowanie społeczeństwa jako całości. W przypadku stwierdzenia przynajmniej czesściowej ich zgodności należy przyjać, $\dot{z}$ e petycja wniesiona została $w$ interesie publicznym. Warto jednak zaznaczyć, że interes publiczny nie musi się odnosić do całego społeczeństwa, lecz może dotyczyć pewnej, nawet małej, grupy wyodrębnionej z uwagi na określona cechę relewantna (np. mieszkańców danego osiedla, studentów określonej szkoły wyższej, osób zagrożonych dana inicjatywa $)^{13}$.

Interpretując pojęcie „interes publiczny”, uznaje się, że: interes ten nie jest zbieżny z pojęciem interesu państwowego, choć krzyżuje się z tym pojęciem. Interes publiczny to też nie interes ogólnospołeczny (wynikający z ochrony dobra wspólnego), gdyż znaczeniowo jest szerszy: każdy interes ogólnospołeczny jest interesem publicznym, ale nie każdy interes publiczny będzie interesem ogólnospołecznym ${ }^{14}$.

W literaturze wskazuje się również, że użyte np. w art. $221 \$ 3$ Kodeksu postępowania administracyjnego (dalej: k.p.a.) (Skargi $i$ wnioski można składać w interesie publicznym, własnym lub innej osoby za jej zgoda) pojęcie „interes publiczny” jest tożsame z pojęciem „interes społeczny”.

łana interesem publicznym, czy też jej motywację musimy definiować w zupełnie inny sposób?

13 S. Gajewski, A. Jakubowski, Petycje, skargi i wnioski, Dział VIII Kodeksu postępowania administracyjnego. Ustawa o petycjach. Komentarz, Warszawa 2015, Legalis, komentarz do art. 2 ustawy.

14 R. Galicki, Wykorzystanie instytucji petycji, wniosków i skarg przez zwiazki zawodowe - analiza dogmatyczna [w:] Skargi, wnioski i petycje - powszechne środki ochrony prawnej, red. M. Błachucki, G. Sibiga, Wrocław 2017, s. 141-142. Autor ten uznaje, że np. zbiorowy interes pracowników jako pewnej grupy społecznej staje się interesem publicznym.

15 W ten sposób: P.M. Przybysz, Kodeks postępowania administracyjnego. Komentarz, 2018, LEX, oraz J. Borkowski [w:] B. Adamiak, J. Borkowski, Kodeks postępowania administracyjnego, Warszawa 2006, s. 831, który przypomniał, że w art. $221 \$ 3$ k.p.a. zastąpiono dawne określenie „interes społeczny” określeniem „interes publiczny” 
Pewne aspekty definicji interesu publicznego (społecznego) zawarte w literaturze prawniczej przedstawiono w uzasadnieniu wyroku Wojewódzkiego Sądu Administracyjnego w Bydgoszczy z 18 czerwca 2008 r. (sygn. akt II SA/ Bd 111/08 ${ }^{16}$. Sąd ten stwierdził: Kategoria interesu społecznego jest pojęciem dynamicznym, stopniowalnym i zmiennym $w$ czasie. Pojęcie to należy każdorazowo rozpatrywać na tle konkretnej sprawy.

Rozważając wprowadzenie proponowanego w petycji ograniczenia upubliczniania skanu odpowiedzi tylko w odniesieniu do petycji wnoszonych w interesie publicznym, należałoby mieć na uwadze potencjalną trudność z ustaleniem w czyim interesie jest wnoszona dana petycja.

Istotny wydaje się przy tym fakt, że wprowadzając w art. 8 ustawy obowiązek zamieszczania skanu petycji nadano publiczny charakter każdej z petycji, nie różnicując go w zależności od tego, czy petycja jest wnoszona w interesie publicznym czy indywidualnym. Ponadto trzeba mieć na względzie, że upublicznieniu (jak mówi art. 11 ust. 4 ustawy: „ogłoszeniu na stronie internetowej”) podlega „sposób załatwienia petycji wielokrotnej” - niezależnie od tego, w czyim interesie są wnoszone dalsze petycje odnoszące się do tej samej sprawy.

Rozpatrzenie petycji - nawet tej wnoszonej w interesie własnym lub w interesie podmiotu trzeciego - stanowiąc realizację ustawowo określonego zadania, będzie dotyczyć sprawy publicznej, a więc może być kwalifikowane jako informacja publiczna ${ }^{17}$. W literaturze stwierdzono, że przepisy ustawy z 6 września 2001 r. o dostępie do informacji publicznej: staną się podstawa do formułowania

i że w doktrynie uznawano, że są to pojęcia ze sobą zamienne. A. Gomułowicz, A.P. Skoczylas, Zakres znaczeniowy - sposób rozumienia „interesu społecznego” (w kontekście innych pojęć niedookreślonych stosowanych przez sądy administracyjne) [w:]

A. Choduń, A. Gomułowicz, A.P. Skoczylas, Klauzule generalne i zwroty niedookreślone w prawie podatkowym i administracyjnym, 2013, LEX, odwołując się do teorii prawa (wedle której kategoria interesu publicznego ma charakter klauzuli generalnej) oraz orzecznictwa stwierdzają, że dokonując interpretacji pojęcia „interes społeczny”, należy mieć na względzie, że: zastosowanie pojęcia nieostrego wymaga wskazania nie tylko jego uwarunkowań zewnętrznych wynikajacych $z$ chronionych wartości zawartych $w$ calym systemie prawa, ale i jego uwarunkowań wynikających $z$ wartości i zasad leżących u podstaw aktu normatywnego, w którym zastosowano dane pojęcie nieostre. Dopiero wtedy dokonana ocena szczegółowo ustalonych okoliczności sprawy nie nosi cech dowolności i mieści się w ramach dopuszczalnego stosowania pojęcia nieostrego.

16 LEX nr 510786.

17 W ten sposób: D. Sybilski, Zagadnienie jawności i dostęp do akt w postępowaniach uproszczonych w sprawach skarg, wniosków i petycji [w:] Skargi, wnioski i petycje - powszechne środki ochrony prawnej, red. M. Błachucki, G. Sibiga, Wrocław 2017, s. 90. Autor ten powołuje się na poglądy wyrażane w doktrynie, jak również w orzecznictwie (wyrok Wojewódzkiego Sądu Administracyjnego w Lublinie z 18 grudnia 2012 r., sygn. akt II SA/Lu 821/12, LEX nr 1351692) co do identyfikacji treści skarg i „efektów” ich rozpatrzenia przez organy publiczne jako informacji publicznej. 
następczych wystąpień ( $w$ zakresie dostępu do informacji publicznych) stużących weryfikacji zapewnień (obietnic, ale również przedstawionych faktów) poczynionych przez adresata petycji ${ }^{18}$.

Mając na względzie powyższe, korzystniejsze wydaje się rozwiązanie, zgodnie z którym upublicznianiu podlegałyby odpowiedzi na wszystkie petycje (po stosownej anonimizacji danych) - a nie tylko te wnoszone w interesie publicznym. Takie rozwiązanie jest również uzasadnione ekonomiką postępowania (w przypadku publikowania skanów odpowiedzi na petycje - brak konieczności przekazywania zainteresowanym tych odpowiedzi w trybie wnioskowym ${ }^{19}$ ).

4. Właściwszym miejscem dla omawianej zmiany wydaje się art. 13 ustawy, który odnosi się do ostatniej fazy postępowania z petycjami, jaką jest zawiadomienie (w formie pisemnej lub elektronicznej) podmiotu wnoszącego petycję „o sposobie jej załatwienia wraz z uzasadnieniem”. Zawiadomienie to należy per analogiam uznać za czynność materialno-techniczną, która kończy postępowanie, tak jak za taką czynność uznaje się zawiadomienie o sposobie załatwienia skargi ${ }^{20}$.

Artykuł 8 odnosi się w sposób wyraźny do etapów poprzedzających tę fazę ${ }^{21}$, a więc do złożenia petycji (zamieszczenia jej skanu na stronie internetowej pod-

W myśl art. 6 ust. 1 pkt 4 ustawy o dostępie do informacji publicznej: Udostępnieniu podlega informacja publiczna, w szczególności o: (...) 4) danych publicznych, w tym:

a) treść i postać dokumentów urzędowych, w szczególności:

- treść aktów administracyjnych i innych rozstrzygnięć,

- dokumentacja przebiegu i efektów kontroli oraz wystapienia, stanowiska, wnioski i opinie podmiotów ja przeprowadzających,

- treść orzeczeń sądów powszechnych, Sądu Najwyższego, sądów administracyjnych, sadów wojskowych, Trybunału Konstytucyjnego i Trybunału Stanu,

b) stanowiska $w$ sprawach publicznych zajęte przez organy władzy publicznej i przez funkcjonariuszy publicznych $w$ rozumieniu przepisów Kodeksu karnego,

c) treść innych wystąień i ocen dokonywanych przez organy władzy publicznej,

d) informacja o stanie państwa, samorządów i ich jednostek organizacyjnych; (...).

18 M. Jabłoński, Prawo dostępu do informacji publicznej a prawo petycji [w:] Teoretyczne i praktyczne aspekty realizacji prawa petycji, red. R. Balicki, M. Jabłoński, Wrocław 2015, s. 336.

19 Czyli na podstawie art. 10 ust. 1 ustawy o dostępie do informacji publicznej, który stanowi: Informacja publiczna, która nie została udostępniona w Biuletynie Informacji Publicznej lub centralnym repozytorium, jest udostęniana na wniosek.

20 Z. Kmieciak, Zarys teorii postępowania administracyjnego, 2014, LEX, oraz wyrok Wojewódzkiego Sądu Administracyjnego w Gorzowie Wielkopolskim z 29 grudnia 2010 r. (sygn. akt II SA/Go 824/10, LEX nr 753182), w którym stwierdzono: Tryb „ogólnoskargowy” (art. 221-240 k.p.a.) jest samodzielnym, jednoinstancyjnym postępowaniem o charakterze uproszczonym, które kończy się czynnościq materialno-techniczna (zawiadomieniem o sposobie załatwienia skargi).

${ }^{21}$ Art. 8. 1. Na stronie internetowej podmiotu rozpatrujacego petycję lub urzędu go obstugujacego niezwłocznie zamieszcza się informację zawierająca odwzorowanie cyfrowe 
miotu rozpatrującego petycję wraz z informacją o dacie jej złożenia i danych podmiotu, który petycję złożył), przebiegu postępowania (polegającego m.in. na zasięganiu opinii) oraz przewidywań co do terminu i sposobu załatwienia petycji.

5. W petycji proponuje się użycie zwrotu „odwzorowanie cyfrowe (skan) odpowiedzi na petycję". Ani w art. 8, ani w art. 13 ustawy nie posłużono się określeniem "odpowiedź na petycję" (pojęcia takiego nie znajdujemy również w pozostałych przepisach ustawy), natomiast w art. 8, 11, 12, 13 i 14 użyto określenia „sposób załatwienia petycji”. Analizując proponowaną w petycji nowelizację art. 8 lub 13 ustawy, należałoby ewentualnie rozważyć ujednolicenie tych pojęć.

Z drugiej jednak strony w doktrynie wskazano, że w klauzuli odsyłającej do ustawy zawartej w art. 63 zdanie drugie Konstytucji RP („Tryb rozpatrywania petycji, wniosków i skarg określa ustawa”) na adresatów m.in. petycji zostały nałożone dwa szczególne obowiązki: rozpatrzenia i udzielenia odpowiedzi autorowi (autorom) petycji ${ }^{22}$. Interpretując na gruncie ustawy pojęcie „sposób rozpatrzenia petycji” uznaje się, że chodzi o: obowiązek sporządzenia uzasadnionej, pisemnej odpowiedzi ustosunkowującej się do żądań, twierdzeń, ocen przedstawionych $w$ petycji $i^{23}$. Jednocześnie stwierdza się, że w świetle art. 63 zdanie drugie Konstytucji RP do obowiązków rozpatrującego petycję należy m.in. „udzielenie odpowiedzi na petycję ze wskazaniem sposobu jej załatwienia"24.

W omawianej kwestii można się również odwołać do interpretacji art. $239 \$ 1$ k.p.a. ${ }^{25}$ (będącego odpowiednikiem art. 12 ustawy): Przez odpowiedź na skargę, o której mowa w początkowej części art. 239 \$1, należy rozumieć zawiadomienie

(skan) petycji, datę jej złożenia oraz - w przypadku wyrażenia zgody, o której mowa w art. 4 ust. 3 - imię i nazwisko albo nazwę podmiotu wnoszacego petycję lub podmiotu, $w$ interesie którego petycja jest składana.

2. Informacja, o której mowa w ust. 1, jest niezwłocznie aktualizowana o dane dotyczace przebiegu postępowania, w szczególności dotyczące zasięganych opinii, przewidywanego terminu oraz sposobu załatwienia petycji.

22 M. Pisz, Gwarancje realizacji konstytucyjnego prawa do petycji w kontekście ustawy $z$ dnia 11 lipca 2014 r. o petycjach, „Przegląd Legislacyjny” 2016, nr 2, s. 54-55. Autor powołuje W. Sokolewicza oraz P. Winczorka.

23 M. Bernaczyk, Postępowanie w przedmiocie rozpatrzenia petycji [w:] Teoretyczne i praktyczne aspekty realizacji prawa petycji, red. R. Balicki, M. Jabłoński, Wrocław 2015, s. 465.

24 M. Jackowski, Prawo petycji a actio popularis [w:] Teoretyczne i praktyczne aspekty realizacji prawa petycji, red. R. Balicki, M. Jabłoński, Wrocław 2015, s. 361.

25 Art. 239. \$1. W przypadku gdy skarga, w wyniku jej rozpatrzenia, została uznana za bezzasadna i jej bezzasadność wykazano w odpowiedzi na skargę, a skarżacy ponowit skarge bez wskazania nowych okoliczności - organ właściwy do jej rozpatrzenia może podtrzymać swoje poprzednie stanowisko $z$ odpowiednia adnotacja w aktach sprawy bez zawiadamiania skarżącego. 
o sposobie rozpatrzenia skargi przedstawiajace stanowisko $w$ sprawie skargi, spetniajace wymagania określone $w$ art. $238^{26}$.

Mając na uwadze powyższe, wydaje się, że w przypadku proponowanej w petycji zmiany nie jest konieczne ujednolicenie pojęć „odpowiedź na petycję” i „sposób załatwienia petycji”.

6. Postulat zmiany art. 6 ust. 1 ustawy został uzasadniony przez wnoszącego petycję tym, że obecny 30-dniowy termin na przesłanie przez adresata petycji podmiotowi właściwemu wydaje się zbyt długi, ponieważ adresat posiada najlepsza wiedzę o swoich zadaniach $i$ kompetencjach $i$ jest $w$ stanie dokonać stosownej oceny petycji w tym obszarze w przeciagu znacznie krótszego czasu. Autor petycji wskazał przy tym art. 231 k.p.a. ${ }^{27}$, który wyznacza adresatowi skargi termin 7-dniowy na przekazanie jej organowi właściwemu, uznając jednocześnie, że brak jest logicznych argumentów, które uzasadniałyby pozostawienie tak długiego terminu w przypadku petycji.

Popierając ten postulat wnoszącego petycję, można przywołać stanowisko, że zadaniem art. 231 k.p.a. jest spowodowanie szybkiego rozstrzygnięcia kwestii właściwości organu do rozpatrzenia skargi ${ }^{28}$. Taki sam 7-dniowy termin został ustalony w art. 243 k.p.a. w odniesieniu do wniosku ${ }^{29}$.

W literaturze wskazuje się, że zróżnicowanie terminów na przekazanie pisma organowi właściwemu w przypadku skargi, wniosku i petycji jest przejawem braku skorelowania przepisów ustawy o petycjach z Kodeksem postępowania administracyjnego ${ }^{30}$. Jednocześnie stwierdza się: Brak (...) racjonalnych argumentów przemawiajacych za 30-dniowym terminem na przekazanie petycji or-

26 P.M. Przybysz, Kodeks postępowania administracyjnego. Komentarz, 2018, LEX. W związku $\mathrm{z}$ nieokreśleniem w ustawie wymogów co do elementów treściowych zawiadomienia o sposobie załatwienia petycji oraz art. 15 ustawy do postępowania z petycjami, należy stosować odpowiednio m.in. art. $238 \$ 1$ k.p.a. [1. Zawiadomienie o sposobie załatwienia skargi powinno zawierać: oznaczenie organu, od którego pochodzi, wskazanie, $w$ jaki sposób skarga została załatwiona, oraz podpis z podaniem imienia, nazwiska i stanowiska służbowego osoby upoważnionej do załatwienia skargi lub, jeżeli zawiadomienie sporzadzone zostało $w$ formie dokumentu elektronicznego, powinno być opatrzone kwalifikowanym podpisem elektronicznym.(...)].

27 Art. 231. Jeżeli organ, który otrzymał skargę, nie jest właściwy do jej rozpatrzenia, obowiązany jest niezwłocznie, nie później jednak niż w terminie siedmiu dni, przekazać ja właściwemu organowi, zawiadamiając równocześnie o tym skarżacego, albo wskazać mu właściwy organ.

28 P.M. Przybysz, Kodeks postępowania administracyjnego. Komentarz aktualizowany, 2018, LEX, komentarz do art. 231 k.p.a.

29 Jeżeli organ, który otrzymat wniosek, nie jest właściwy do jego rozpatrzenia, obowiązany jest w ciagu siedmiu dni przekazać go właściwemu organowi. O przekazaniu wniosku zawiadamia się równocześnie wnioskodawcę.

30 M. Ożóg, Uregulowanie instytucji, op. cit., s. 133. 
ganowi właściwemu, zwłaszcza że $w$ dziale VIII k.p.a., który również wykonuje art. 63 Konstytucji, termin przekazania skargi lub wniosku organowi właściwemu następuje nie później niż w ciagu 7 dni (por. art. 231 i 243 k.p.a.).

Takich argumentów nie wskazano w uzasadnieniu senackiego projektu ustawy o petycjach (druk sejmowy nr 2135/VII kad.) ${ }^{32}$, a jednocześnie w trakcie prac legislacyjnych nad tym przedłożeniem w opiniach na jego temat zgłaszano zastrzeżenia co do omawianego terminu ${ }^{33}$.

Wobec powyższego postulat zmiany art. 6 ust. 1 ustawy zgłoszony w petycji jest w pełni zasadny.

\section{Podsumowanie}

Obie zmiany ustawy z 11 lipca 2014 r. o petycjach w zakresie proponowanym w petycji wydają się uzasadnione i są dopuszczalne z punktu widzenia swobody ustawodawcy. Za ich pozytywną oceną przemawia m.in. dotychczasowa praktyka i poglądy wyrażane w doktrynie.

Proponowana zmiana art. 8 ustawy uzyskała wcześniej rekomendację Biura Analiz Sejmowych ${ }^{34} \mathrm{z}$ uwagi na to, że taka nowelizacja służyłaby transparentności procesu postępowania z petycjami (m.in. w kontekście obywatelskiego prawa do informacji gwarantowanego w art. 61 Konstytucji RP) oraz likwidowałaby „nie-

31 E. Wójcicka, Ustawa z dnia 11 lipca 2014 r. o petycjach - uwagi krytyczne, „Ruch Prawniczy, Ekonomiczny i Socjologiczny” 2017, nr 1, s. 167.

32 Art. 7 projektu (czyli art. 6 ustawy) zawiera następujący fragment: Projekt ustawy przewiduje zasadę działania adresatów petycji w ramach ich właściwości, która powinna być ustalana stosownie do materii, której petycja dotyczy i zakresu kompetencji podmiotu niezbędnego do jej rozpatrzenia. Podmiot, do którego błędnie wniesiono petycję, jest obowiązany do przekazania jej właściwemu podmiotowi (art. 7).

33 M. Florczak-Wątor w Opinii prawnej na temat senackiego projektu ustawy o petycjach (druk nr 2135) z 7 kwietnia 2014 r. stwierdza: Poważne wątpliwości rodza również wskazane w projekcie terminy rozpatrzenia petycji. Wynikajacy $z$ art. 7 projektu termin maksymalny 30 dni na przekazanie petycji przez jej adresata do podmiotu właściwego do jej rozpatrzenia jest zbyt długi, zważywszy na to, że poza stwierdzeniem swej niewłaściwości adresat petycji na tym etapie postępowania nie podejmuje żadnych innych działań, zaś samo przekazanie petycji jest czynnością techniczną. Moim zdaniem wystarczajacy byłby termin maksymalny 7 dni, czyli taki sam jaki art. 231 i art. 243 k.p.a. ustanawiają dla czynności przekazywania organom właściwym skarg i wniosków do rozpatrzenia, http://orka.sejm.gov.pl/rexdomk7.nsf/Opdodr?OpenPage\&nr=2135. Podobna uwaga została zgłoszona w „Uwagach woj. opolskiego do senackiego projektu ustawy o petycjach” z dnia 30 stycznia 2014 r., http://orka.sejm.gov.pl/Druki7ka.ns f/0/468173F83ED010BFC1257C7D0044FEB7/\%24File/2135.pdf.

34 Opinia prawna dotyczaca petycji A.H. $z$ dnia 28 grudnia 2016 r. do Marszałka Sejmu w sprawie podjęcia działań w celu zmiany ustawy o petycjach, BAS-WAUiP 364/17. 
symetryczność" polegającą na obowiązku publikowania skanu petycji i braku takiego obowiązku w odniesieniu do odpowiedzi udzielonej wnoszącemu petycję.

Ponieważ w przypadku skarg i wniosków (rozpatrywanych na podstawie działu VIII k.p.a.) termin na przekazanie skargi (wniosku) według właściwości wynosi 7 dni, zasadne byłoby skrócenie takiego terminu również przy rozpatrywaniu petycji, np. do $14 \mathrm{dni}$ (czyli tak, jak to zaproponowano w petycji w ramach nowelizacji art. 6 ustawy).

$\mathrm{W}$ analizowanej petycji przedstawiono koncepcję legislacyjną, a w związku $\mathrm{z}$ tym postulaty zgłaszane przez jej autora mogą stanowić podstawę do podjęcia konkretnych prac nad zmianą prawa.

\section{Bibliografia}

Bernaczyk M., Postępowanie w przedmiocie rozpatrzenia petycji [w:] Teoretyczne i praktyczne aspekty realizacji prawa petycji, red. R. Balicki, M. Jabłoński, Wrocław 2015.

Borkowski J. [w:] B. Adamiak, J. Borkowski, Kodeks postępowania administracyjnego, Warszawa 2006.

Gajewski S., Jakubowski A., Petycje, skargi i wnioski, Dział VIII Kodeksu postępowania administracyjnego. Ustawa o petycjach. Komentarz, Warszawa 2015.

Galicki R., Wykorzystanie instytucji petycji, wniosków i skarg przez związki zawodowe analiza dogmatyczna [w:] Skargi, wnioski i petycje - powszechne środki ochrony prawnej, red. M. Błachucki, G. Sibiga, Wrocław 2017.

Gomułowicz A., Skoczylas A.P., Zakres znaczeniowy - sposób rozumienia „interesu społecznego" ( $w$ kontekście innych pojęć niedookreślonych stosowanych przez sądy administracyjne) [w:] Klauzule generalne $i$ zwroty niedookreślone w prawie podatkowym i administracyjnym, A. Choduń, A. Gomułowicz, A.P. Skoczylas, 2013, LEX.

Jabłoński M., Prawo dostępu do informacji publicznej a prawo petycji [w:] Teoretyczne i praktyczne aspekty realizacji prawa petycji, red. R. Balicki, M. Jabłoński, Wrocław 2015.

Kmieciak Z., Zarys teorii postępowania administracyjnego, 2014, LEX.

Ożóg M., Uregulowanie instytucji petycji w ustawie $z$ dnia 11 lipca 2014 r. o petycjach, „Przegląd Sejmowy” 2015, nr 5(130).

Pisz M., Gwarancje realizacji konstytucyjnego prawa do petycji w kontekście ustawy z dnia 11 lipca 2014 r. o petycjach, „Przegląd Legislacyjny” 2016, nr 2.

Preisner A., Kuczma P., Zakres przedmiotowy prawa petycji i jego ograniczenia [w:] Teoretyczne i praktyczne aspekty realizacji prawa petycji, red. R. Balicki, M. Jabłoński, Wrocław 2015.

Przybysz P.M., Kodeks postępowania administracyjnego. Komentarz, 2018, LEX.

Sybilski D., Zagadnienie jawności i dostęp do akt w postępowaniach uproszczonych $w$ sprawach skarg, wniosków i petycji [w:] Skargi, wnioski i petycje - powszechne środki ochrony prawnej, red. M. Błachucki, G. Sibiga, Wrocław 2017.

Wójcicka E., Ustawa z dnia 11 lipca 2014 r. o petycjach - uwagi krytyczne, „Ruch Prawniczy, Ekonomiczny i Socjologiczny" 2017, nr 1, https://doi.org/10.14746/rpeis.2017.79.1.12. 